\title{
Firm Performance and the Strategic Components of Bankruptcy Reorganization Plans
}

\author{
Guilherme Fowler A. Monteiro ${ }^{1}$ \\ Silvia Morales de Q. Caleman ${ }^{2}$ \\ Leandro S. Pongeluppe ${ }^{3}$ \\ ${ }^{1}$ Insper Instituto de Ensino e Pesquisa, São Paulo, SP, Brazil \\ ${ }^{2}$ Universidade Federal de Mato Grosso do Sul, Campo Grande, MS, Brazil \\ ${ }^{3}$ University of Toronto, Toronto, Canada
}

Received 31 May 2019. This paper was with the authors for two revisions. Accepted 27 January 2020. First published online 27 February 2020.

Renan Felinto de Farias Aires was the associate editor for this article.

Editorial assistant: Luciane Kato Kiwara

Editor-in-chief: Carlo Gabriel Porto Bellini 


\section{Abstract}

We investigate the influence of bankruptcy reorganization plans on the recovery of distressed firms. Using qualitative comparative analysis (QCA), specifically, we perform an in-depth investigation of a set of reorganization plans submitted by publicly traded companies in Brazil. We find that the improvement in firm performance is positively related to a good diagnosis of the factors causing the crisis, a clear definition of the firm's resources, and a clear identification of the firm's competitive strengths. We also find that the absence of a good industry analysis is a critical condition for a reorganization plan to fail. However, the explicit mentioning of the firm's relevant market is negatively associated with the company's uplifting in crisis. We discuss the theoretical and managerial implications of these findings.

Keywords: business failure; reorganization plan; bankruptcy protection; strategy. 


\section{Introduction}

When a company faces failure in business, it usually follows one of two paths. The firm may seek an out-of-court agreement with its creditors, or it may go bankrupt. In the latter case, the firm may file for a liquidation bankruptcy, meaning that it ceases its operations and agrees to dispose of its assets so that the creditors receive at least a portion of the amount they are owed. Alternatively, the company may file for a reorganization bankruptcy. In this case, creditors' claims are postponed while the company undertakes actions with the deliberate intention to restructure its operations.

The basic assumption of reorganization bankruptcy is the ability of a distressed firm to "convince creditors it can succeed in the marketplace by implementing a new strategic plan and that when the plan produces profits, the company will be able to repay its creditors" (Pearce \& DiLullo, 1998, p. 67). Therefore, one of the most important elements of reorganization bankruptcy is reorganization plans. If a plan is consistent, there are chances for the company to restructure itself and overcome the crisis. If a plan is inconsistent, represents only pages devoid of meaning, and has the sole purpose of meeting legal prerequisites, then the recovery of the company can never occur.

Given the role of reorganization plans in the recovery of distressed firms, we perform an exploratory analysis of the strategic components of the plans. Our main objective is to identify the most prominent strategic elements of bankruptcy reorganization plans and how they connect to firm performance. To accomplish this task, we perform an in-depth investigation of a set of plans, linking its strategic components to the performance of firms under reorganization bankruptcy by means of a qualitative comparative analysis (QCA).

We develop our study in Brazil. The country has a history of crises, which makes it an interesting case to analyze the issue. For example, Brazil is famously known for economic volatility in a context of high inflation rates in the 1980s and 1990s. More recently, a combination of political and economic issues plunged the country into a severe crisis in the aftermath of the global meltdown of 2008. Bellini, Palvia, Moreno, Jacks and Graeml (2019) assert that the country's recent crisis can be divided into two moments. The first, called the pre-awareness moment, occurred in the first half of 2015. During this period, citizens did not have a clear understanding of the depth and breadth of the crisis. The second moment, in the first half of 2016, was characterized by the government's admission about the seriousness of the crisis, which was already strongly affecting the lives of people and businesses. From June 2005 (when the bankruptcy law in force was passed in Brazil) until September 2019, there were 60,543 reorganization bankruptcy requests granted by the courts in the country. Of this total, $54 \%$ of requests were made by micro and small companies, $29 \%$ by medium businesses and $17 \%$ by large companies (Serasa Experian, 2019).

In this paper, we develop our argument in two steps. First, we examine the theoretical aspects of reorganization bankruptcy and outline a simple model of the strategic components of a reorganization plan. Second, we present our empirical analysis, describing the sample, the 
variables and the fuzzy-set QCA methodology. Based on our analysis, we find that managers involved in corporate reorganization processes must pay particular attention to four elements: (a) the diagnosis of the factors causing the crisis, (b) the resources owned by the firm, (c) the industry analysis, and (d) the identification of the firm's competitive strengths. Specifically, our results suggest that the absence of an industry analysis is associated with a decline in the financial situation of the firm, which is in line with the traditional predictions of the strategy literature (McGahan \& Porter, 1997; Porter, 1985). However, the explicit mentioning of the firm's relevant market is negatively associated with the company's uplifting in crisis.

The results above make two important contributions to the literature. First, we expand the debate on business turnaround and reorganization bankruptcy by shedding light on an antecedent that has not yet received much attention, namely the bankruptcy reorganization plan. In doing so, we deepen knowledge about the determinants of successful turnarounds (Boyne \& Meier, 2009; D. D. Baker \& Cullen, 1993; Schweizer \& Nienhaus, 2017; V. L. Baker \& Duhaime, 1997). Specifically, we bring insights into the turnaround strategies used by companies (Schweizer \& Nienhaus, 2017) and the decision process and practice in times of organizational failure (Serra, Pinto, Guerrazzi, \& Ferreira, 2017). Second, by mapping the strategic components of reorganization plans, we develop a holistic view of the strategic building process. This contributes to the debate on the theoretical integration of the different strategic elements (Hooley \& Greenley, 2005; Madhok, 2002; Mahoney \& Pandian, 1992; Nickerson, Hamilton, \& Wada, 2001; Sheehan \& Foss, 2017).

\section{Background}

\section{Reorganization bankruptcy and reorganization plans}

When a company goes into reorganization bankruptcy, its leaders generally formulate a turnaround strategy hoping to convince investors and creditors that the return to profitability is achievable. The usual turnaround process is designed to reverse the negative situation of the company and make it return to or exceed pre-crisis performance levels (Hofer, 1980; Lim, Celly, Morse, \& Rowe, 2013; O’Neill, 1986; Trahms, Ndofor, \& Sirmon, 2013).

Specifically examining the turnaround process, Pearce and Robbins (1993) divide it into two stages: turnaround situation and turnaround response ${ }^{1}$. The turnaround situation stage occurs when a firm faces multiple periods of decline in its financial performance after a relatively long, stable period of prosperity. Turnaround situations are caused by a combination of external and internal factors that may generate circumstances with different degrees of severity, ranging from a reduction in margins and sales to bankruptcy. The turnaround response stage, in turn, can usually be divided into two phases: retrenchment and recovery ${ }^{2}$. The primary objective of the retrenchment phase is to produce the financial stabilization of the company. To this end, managers seek to raise the firm's efficiency by reducing costs and assets relative to the earnings generated. The intent of retrenchment is to enable the recovery of the firm through maintenance of efficiency and/or the entrepreneurial reconfiguration of the firm (Pearce \& Robbins, 1993). 
Considering these two stages of the turnaround process, Pearce and DiLullo (1998) argue in favor of a strategic plan that openly incorporates the possibility of firm bankruptcy (see also Flynn \& Farid, 1991; Moulton \& Thomas, 1993). According to Pearce and DiLullo (1998), the possibility of bankruptcy can be explicitly incorporated into the strategic planning of a firm when one contemplates the turnaround situation as a potential bankruptcy situation. Based on this argument, our basic claim in this paper is that the inclusion of a strategic planning exercise into the turnaround stage sheds light on another stage so far disregarded in the majority of turnaround discussions: the stage of reorganization plan formulation. In line with most statutory schemes, the plan must be accepted by the majority of creditors, and the plan's feasibility must be confirmed by the bankruptcy court. Thus, the reorganization plan is a key element of the turnaround process when it involves bankruptcy protection. The plan formulation phase takes place after the bankruptcy situation and precedes the turnaround response (see Figure 1).

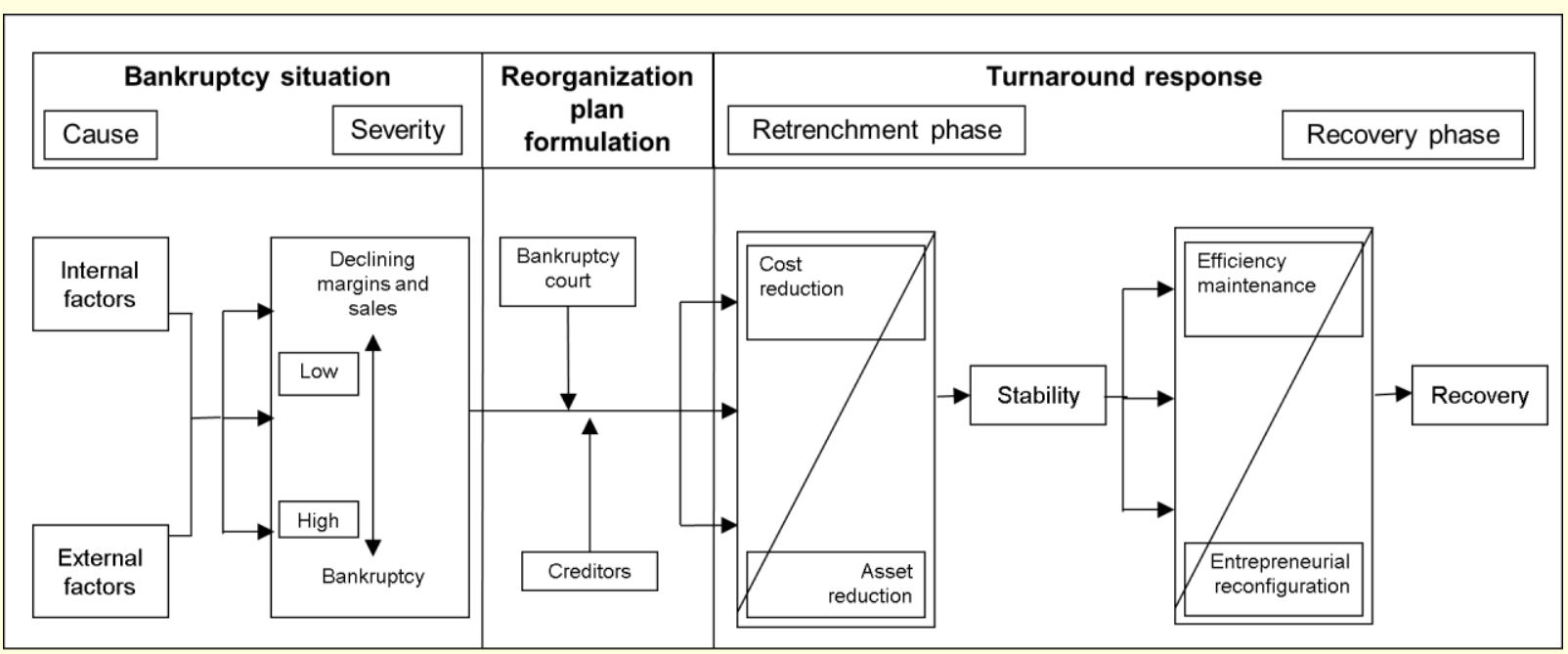

Figure 1. Extended bankruptcy recovery model

Source: elaborated by the authors, based on Pearce, J. A., \& DiLullo, S. A. (1998). When a strategic plan includes bankruptcy. Business Horizons, 41(5), 67-73. https://doi.org/10.1016/s0007-6813(98)90080-5, and Pearce, J. A., \& Robbins, D. K. (1993). Toward improved theory and research on business turnaround. Journal of Management, 19(3), 613-636. https://doi.org/10.1177/014920639301900306

Subject to local jurisdiction, a company seeking bankruptcy protection has a specific number of days to present its reorganization plan, which has to be accepted by a precise number of creditors within each class of creditors $^{3}$. In Brazil, the reorganization plan must be submitted within 60 days after the decision granting the judicial reorganization (Lei no. 11.101, 2005). Together with the creditors, the plan must also be confirmed by the court. A court can confirm a reorganization plan only if it believes that the confirmation "is not likely to be followed by the liquidation, or the need for further financial reorganization, of the debtor or any successor to the debtor under the plan, unless such liquidation or reorganization is proposed in the plan" (section 1129(a)(11) of the US Bankruptcy Code, Confirmation of Plan, 2019). This type of assessment is performed in Brazil by the judge responsible for reviewing the request for judicial recovery (see, for instance, Vaz, 2018). This is generally referred to as the feasibility test. The test does not require the guaranteed success of the plan. The firm must show only that there is reasonable assurance of compliance with the terms of the plan. In other words, the test requires a demonstration of the likelihood of the plan will be accomplished, not its success (Baldiga, 1996). 
In fact, a good reorganization plan is not itself a guarantee to uplift a company in crisis. Macroeconomic factors, increased competition, or even the failure of the plan's execution can compromise the intended reorganization. However, the relevance of the present investigation should not be underestimated; the reorganization plan is the heart of the process of reorganization bankruptcy. A reorganization plan is the roadmap for a firm's turnaround, as expressed by its managers. It is also the core element whose feasibility the court assesses to decide on the request for reorganization. In this sense, our study makes an explicit link between strategy and bankruptcy (Daily, 1994; Sheppard, 1994; Trahms et al., 2013). More specifically, the reorganization plan is important because it brings empirical evidence on two research gaps, namely: the turnaround strategies that goes beyond retrenchment (Schweizer \& Nienhaus, 2017) and the strategic decision process and practice under organizational decline (Serra et al., 2017). The examination of reorganization plans, moreover, is in line with recent studies that use documentary, qualitative evidence in the context of corporate decline (Muñoz-Izquierdo, SegoviaVargas, Camacho-Miñano, \& Pascual-Ezama, 2019).

\section{The strategic ingredients of the reorganization plan}

As stated, a reorganization plan is the document by which firm managers present their planning for the financial restructuring of the firm as well as the strategic rationale for the continuation of its operations. Because creditors and the court must approve a reorganization plan, the plan tends not to include sensitive strategic details as they may fall on the ears of competitors. However, the plan should be detailed enough to convince stakeholders about the feasibility of recovery. The reorganization plan, therefore, is based on a delicate balance.

The most apparent strategic element of a reorganization plan is the list of recovery means to be employed by the firm. Such recovery means involve, but are not necessarily limited to, retrenchment actions - i.e., the cost reduction and asset reduction of the firm. Another important element of the plan is the diagnosis of the factors that may have caused the crisis. It is expected that the means of recovery and the diagnosis maintain a close relationship with each other.

Focusing only on diagnosis and recovery means, however, can cover significant aspects. A reorganization plan can be viewed as top management team's expression of a broad understanding of its own current situation and how it plans to overcome the crisis. Put differently, a reorganization plan can be analyzed in itself, being a portrait of the company for its own management. The ultimate goal of a reorganization plan is to pave the way for the firm to obtain or retrieve a sustainable competitive advantage. Since the strategy of the firm does not occur in a vacuum, it goes without saying that planning for competitive advantage (i.e., reorganization plan) should also consider a set of strategic ingredients. These ingredients are the intermediate steps, which connect the diagnosis of the crisis and the selection of recovery mechanisms. They are the internal gearing of the reorganization plan. 
From a theoretical perspective, and for the sake of simplicity, we focus on four fundamental strategic ingredients that can be described as an ordered list of assessments. The first ingredient is the formulation of a diagnosis of the factors causing the crisis (e.g., D'Aveni, 1989; Thornhill $\&$ Amit, 2003). The next step is the clear definition of the market in which the firm operates (see Besanko, Dranove, Shanley, \& Schaefer, 2009), as well as any change in this market caused either by exogenous factors or by the dynamics of innovation (e.g., Pleatsikas \& Teece, 2001). This step should not be overlooked because firm managers must be able to clearly articulate the competitive space in which the firm operates - especially because the reorganization plan will be scrutinized by the court, which does not necessarily have knowledge on the industry. The third step is to conduct an analysis of the competitive components of the industry (Porter, 1985) and the internal resources of the firm (e.g., Barney, 1991; Peteraf, 1993). These elements allow managers to identify more clearly the competitive strengths and weaknesses of the company and thus formulate a coherent recovery strategy. Figure 2 summarizes these steps.

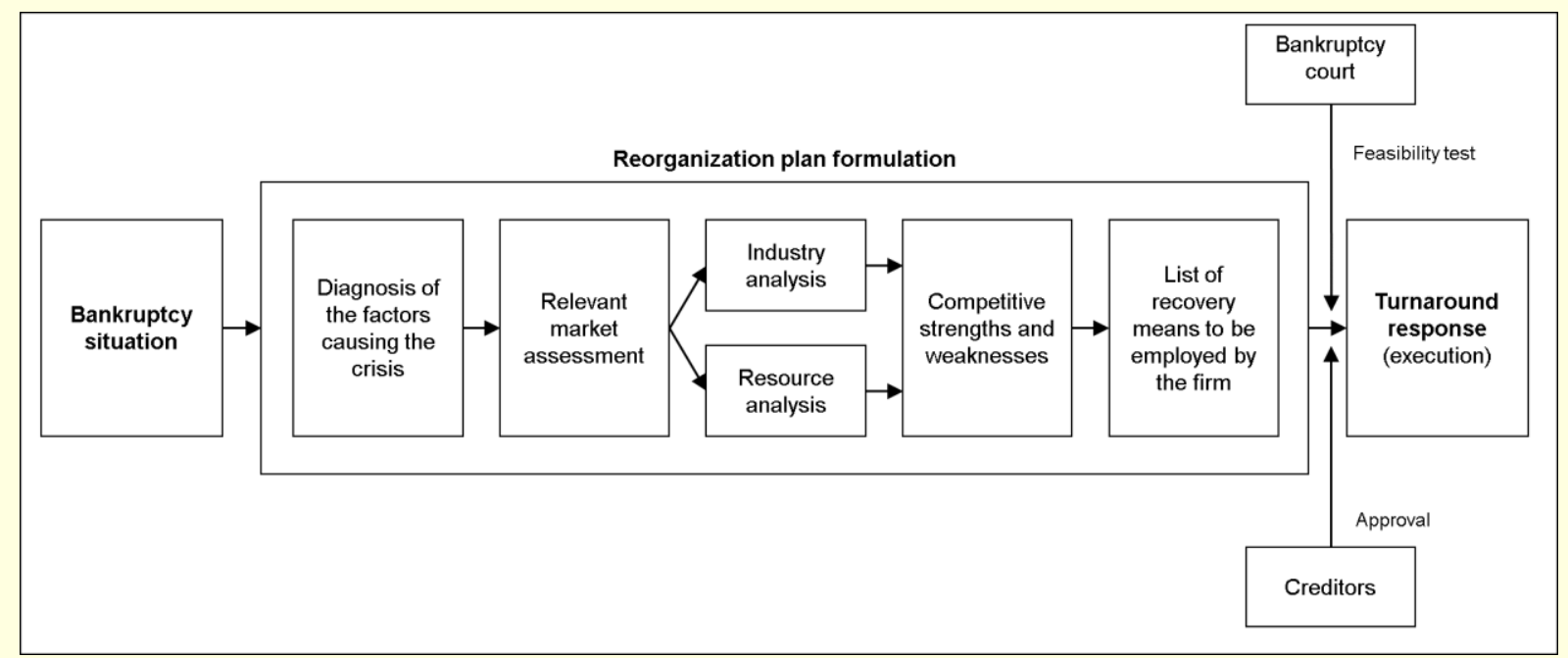

Figure 2. Model of strategic components of the reorganization plan

Largely, the intermediate steps of a plan reflect the competence of the firm in analyzing the interface between the business environment and the company's own characteristics. This demonstrates the ability of the firm to understand its sources of competitive advantage, leading to our interest in reading between the lines of a plan as a proxy of a company's strategic competence. We are not interested merely in the recovery means employed by companies. We want to understand how the design of a plan may affect the performance of the firm. Accordingly, taking as a reference the discussion on the strategic ingredients of reorganization plans, we now present our empirical analysis. We base our investigation on reorganization plans developed by publicly traded companies in Brazil. To accomplish this task, we set up a unique database and develop a specific performance measure. 


\section{Method}

\section{Context and sample}

Bankruptcy proceedings in Brazil were originally governed by Decree-Law No. 7,661 (Decreto-lei no. 7.661, 1945), which was considered inefficient and time-consuming (Araujo \& Funchal, 2009). With the deliberate intention to modernize, accelerate, and make the bankruptcy process more transparent, the New Brazilian Bankruptcy Law (Lei no. 11.101, 2005) was promulgated in 2005. The main inspiration of the Brazilian Law was the US Bankruptcy Code, with which it holds strong similarities (Anapolsky \& Woods, 2013; Araujo, Ferreira, \& Funchal, 2012) ${ }^{4}$. According to Funchal (2008), following the enactment of Law No. 11,101 (Lei no. 11.101, 2005), there was a $22 \%$ reduction in corporate debt costs, a $39 \%$ increase in credit levels, and an increase in short- and long-term credit flow.

Pursuant to the law, each application for bankruptcy reorganization in Brazil is associated with a reorganization plan; this represents the domain of interest for the present research. It just so happens, however, that the vast majority of cases involves the reorganization of private companies. As a result, although reorganization plans are disclosed to creditors and plan discussion meetings are open to any person, it is not possible for researchers to obtain a hardcopy or an electronic copy of the plans of private companies ${ }^{5}$. On the other hand, in the case of listed companies, access to the reorganization plan is possible through the Stock Exchange's website (bmfbovespa.com.br). Thus, we focus our study on the reorganization plans of Brazilian public companies.

We selected 10 companies that have shares traded in Brazil's stock exchange and went through bankruptcy reorganization supported by Law 11,101 (see Table 1). All companies have long been in operation, some of them centuries old. Most companies went public in the twentieth century. Firms have operations in various industries, particularly the textile and energy industries. They have regional, national, and international operations. 
Table 1

\section{Brazilian listed companies under bankruptcy protection, 2005-2013}

\begin{tabular}{|c|c|c|c|c|c|c|}
\hline Company & $\begin{array}{l}\text { Company } \\
\text { name }\end{array}$ & $\begin{array}{l}\text { Year of } \\
\text { foundation }\end{array}$ & $\begin{array}{l}\text { Year of } \\
\text { IPO }\end{array}$ & $\begin{array}{l}\text { Initial year of } \\
\text { bankruptcy } \\
\text { protection }\end{array}$ & $\begin{array}{l}\text { Reorganization } \\
\text { plan size } \\
\text { (n. pages) }\end{array}$ & Description \\
\hline 1 & Buettener & 1898 & 1969 & 2011 & 45 & $\begin{array}{l}\text { The company operates in the textile production industry (bed and table linen). It has made } \\
\text { investments in private label development, selling its products in both domestic and international } \\
\text { markets. }\end{array}$ \\
\hline 2 & Celpa & 1962 & 1999 & 2012 & 35 & $\begin{array}{l}\text { The company operates in the segment of generation, distribution, and commercialization of } \\
\text { energy, being the second largest energy distributor in Northeast Brazil in terms of concession } \\
\text { area. }\end{array}$ \\
\hline 3 & Chiarelli & 1936 & 1971 & 2008 & 36 & $\begin{array}{l}\text { The firm operates in the production and sale of ceramic tiles for walls and floors, working in } \\
\text { national and international markets (North America, Central America, Africa, Europe, and Oceania). }\end{array}$ \\
\hline 4 & GPC & 1929 & 1997 & 2013 & 34 & $\begin{array}{l}\text { It is a holding company that involves (i) a chemical firm (production of thermosetting resins and } \\
\text { methanol) with significant participation in the national market ( } 25 \% \text { market share) and (ii) a firm } \\
\text { devoted to the production of conduits and carbon steel tubes aimed at infrastructure, construction, } \\
\text { and the automotive market. This business unit has over } 2,000 \text { clients among resellers, distributors, } \\
\text { construction companies, automakers, and steel tube applicators. }\end{array}$ \\
\hline 5 & RedeE & 1903 & 2006 & 2012 & 48 & It is one of the largest private business groups in the Brazilian energy industry. \\
\hline 6 & Sansuy & 1966 & 1980 & 2006 & 57 & $\begin{array}{l}\text { The firm produces and sells plastic goods in general. The company primarily operates in the } \\
\text { segment of the manufacture of products based on polymerizing vinyl chloride (PVC). This is a } \\
\text { product used in the composition of materials for advertising (banners), sheds, soil, and } \\
\text { environment protection, agriculture (nets for fish farming; curtains for farms and silos), and } \\
\text { logistics (cargo cover). The company has a significant market share, reaching } 76 \% \text { in } 2004 \\
\text { (according to the company's own calculations). }\end{array}$ \\
\hline 7 & Schlosser & 1933 & 1971 & 2010 & 24 & $\begin{array}{l}\text { The company is primarily engaged in the production, manufacturing, and marketing of clothing } \\
\text { fabrics using natural and artificial fibers. The company has a production capacity of } 1.2 \text { million } \\
\text { square meters of fabric per month and performs the spinning, weaving, dyeing, printing, and } \\
\text { finishing of fabrics. }\end{array}$ \\
\hline
\end{tabular}


Table 1 (continued)

\begin{tabular}{|c|c|c|c|c|c|c|}
\hline Company & $\begin{array}{l}\text { Company } \\
\text { name }\end{array}$ & $\begin{array}{l}\text { Year of } \\
\text { foundation }\end{array}$ & $\begin{array}{l}\text { Year of } \\
\text { IPO }\end{array}$ & $\begin{array}{l}\text { Initial year of } \\
\text { bankruptcy } \\
\text { protection }\end{array}$ & $\begin{array}{l}\text { Reorganization } \\
\text { plan size } \\
\text { (n. pages) }\end{array}$ & Description \\
\hline 8 & Sjose & 1911 & 1985 & 2011 & 53 & $\begin{array}{l}\text { The firm is engaged in the manufacture and trade of cotton yarns and fabrics, especially twills and } \\
\text { indigo. Products manufactured by the company supply large wholesalers and small garment- } \\
\text { selling companies throughout Brazil, with greater emphasis in the states of Pernambuco } \\
\text { (Northeast Brazil) and São Paulo (Southeast). The company has an estimated monthly production } \\
\text { capacity of } 500 \text { tons of yarn and } 1 \text { million linear meters of fabric. }\end{array}$ \\
\hline 9 & Tecnosolo & 1957 & 1973 & 2012 & 211 & $\begin{array}{l}\text { It is a well-known Brazilian consulting company focused on geology and engineering projects for } \\
\text { various industries, such as transportation and the construction of ports, refineries, thermal power } \\
\text { plants, and sports arenas, among others. The company is known for its efforts in developing } \\
\text { research and new ground technologies. }\end{array}$ \\
\hline 10 & Teka & 1926 & 1968 & 2013 & 160 & $\begin{array}{l}\text { Business group operating in the textile industry with the production and sale of bed and table linen. } \\
\text { It has invested in the development of its own brand, and it performs activities in domestic and } \\
\text { international markets. Currently, the company produces more than ten thousand tons of smooth } \\
\text { and terry cloth a year and has nearly three thousand employees in five production plants. }\end{array}$ \\
\hline
\end{tabular}

Note. Source: elaborated by the authors based on data obtained from bmfbovespa.com.br. 


\section{Measures}

The reorganization plans of the companies described in Table 1 are the key input of our investigation. In line with the model presented in Figure 2, we examine the contents of the plans regarding the diagnosis of the problem faced by the company, the definition of the relevant market, the identification of internal resources and competitive forces, and the articulation of the competitive strengths and weaknesses of the company.

Each reorganization plan was analyzed in depth by the three authors. Two steps were performed. First, the plans were assessed and their content was tabulated in each dimension of the analysis (see Table 4). Then, each dimension was examined separately and ranked on a scale according to plan quality (see Appendix). To build this ranking, each author performed separate assessments of the plans. The final ranking was the average of each individual assessment. The descriptive statistics and correlations of the strategic dimensions are presented in Table 2.

Table 2

\section{Descriptive statistics and correlations}

\begin{tabular}{|c|c|c|c|c|c|c|c|c|}
\hline & Strategic dimension & Mean & SD & 1 & 2 & 3 & 4 & 5 \\
\hline 1 & Diagnosis & 1.77 & 1.13 & 1.000 & & & & \\
\hline 2 & Relevant market & 1.77 & 0.77 & -0.437 & 1.000 & & & \\
\hline 3 & Resource analysis & 1.37 & 1.00 & $0.683^{*}$ & $-0.581^{*}$ & 1.000 & & \\
\hline 4 & Industry analysis & 1.20 & 1.21 & $0.768^{*}$ & -0.065 & 0.474 & 1.000 & \\
\hline 5 & $\begin{array}{l}\text { Competitive strengths and } \\
\text { weaknesses }\end{array}$ & 0.83 & 0.98 & 0.526 & -0.173 & $0.722^{*}$ & 0.509 & 1.000 \\
\hline
\end{tabular}

Note. The standard deviations are close to the mean, which is usually a feature of exponential distributions. In our case, this is due to the combination of a 4- to 5-point Likert scale with a small sample size of cases, which hurdle the possibility of achieving a normal distribution within the constructs.

* $5 \%$ significance.

To assess the consistency of the ranking, we performed reliability tests. We computed the Cronbach's $\alpha$ (alpha) test and the Cohen's $\kappa$ (kappa) test. The first one is a measure of internal consistency used to assess the correlation among the rankings of distinct raters (Cronbach, 1951). The second one measures the level of agreement among different rankings under the null hypothesis that agreement among raters has been randomly determined (Cohen, 1960). As described in Table 3, the tests indicate that the quality rankings are consistent. 
Table 3

Reliability tests

\begin{tabular}{cccc}
\hline Company & Company name & Cronbach's $\boldsymbol{\alpha}$ (alpha) & $\begin{array}{c}\text { Cohen's K (kappa) } \\
\text { [Prob }>\text { Z] }\end{array}$ \\
\hline 1 & Buettener & 0.9025 & 0.0206 \\
2 & Celpa & 0.9796 & 0.0015 \\
3 & Chiarelli & 0.9000 & 0.0024 \\
4 & GPC & 0.8824 & 0.0000 \\
5 & RedeE & 1.0000 & 0.0001 \\
6 & Sansuy & 0.7660 & 0.0481 \\
7 & Schlosser & 0.9524 & 0.0086 \\
8 & Sjose & 0.8721 & 0.0258 \\
9 & Tecnosolo & 0.8143 & 0.0717 \\
10 & Teka & 0.8750 & 0.0232 \\
\hline
\end{tabular}

Note. It is desirable that Cronbach's $\alpha>0.7$; Cohen's k should be $p<0.05$ (see Cohen, 1960; Cronbach, 1951). Cronbach's a indicated internal reliability among raters; this implies that all raters, regardless of each other, had a similar assessment with respect to reorganization plans. Cohen's $\mathrm{k}$ indicated that the reliability tests are statistically different from what would have been a random assessment. These two measures validate the assessment of each reorganization plan.

Regarding firm performance, we built an indicator based on the EBITDA of each company (financial data were obtained from Capital IQ, www.capitaliq.com). EBITDA is an acronym for earnings before interest, taxes, depreciation, and amortization. It represents the operating cash flow of the company, i.e., how much money the firm generates only in its operations, not considering the financial and tax effects. The use of EBITDA in our research is an appropriate measure because it represents the firm's own ability to generate financial resources to overcome its crisis.

To create our indicator, we calculated the ratio of the average EBITDA for each company, taking as a reference the periods before and after the bankruptcy ${ }^{6}$. The period before bankruptcy refers to the three years immediately preceding the bankruptcy of the company. We calculated the threeyear average EBITDA because companies that are about to go bankrupt usually have sharp fluctuations in financial indicators. Thus, the average corrects any seasonality or abrupt movements of the indicators ${ }^{7}$. For the period after the bankruptcy, we calculated the average EBITDA considering the period initiating after the two-year reorganization bankruptcy period because it is the time provided by law for the recovery of the company. For the calculation of this average, the period considered varies from one to three years, depending on the availability of data (which depends on the initial year of bankruptcy protection). When calculating the EBTIDA ratio, we applied the modulus in the denominator. This is a simplification of the normalized earnings approach (Damodaran, 2001), which ensures the identification of the actual improvement or worsening of the financial condition of the firm. The results are shown in the last column in Table 4. 
Table 4

Strategic dimensions of the reorganization plans and EBITDA ratio

\begin{tabular}{|c|c|c|c|c|c|}
\hline Company & $\begin{array}{l}\text { Relevant market } \\
\text { assessment }\end{array}$ & Resource analysis & $\begin{array}{l}\text { Industry } \\
\text { analysis }\end{array}$ & $\begin{array}{l}\text { Discussion on } \\
\text { competitive } \\
\text { strengths and } \\
\text { weaknesses }\end{array}$ & Ratio $_{\text {EBITDA }}$ \\
\hline Buettener & - & $\begin{array}{l}\text { Infrastructure and } \\
\text { brand }\end{array}$ & $\begin{array}{l}\text { Substitute } \\
\text { products }\end{array}$ & Yes & $-0,44$ \\
\hline Celpa & $\begin{array}{l}\text { Identification of } \\
\text { geographic scope and } \\
\text { products and services }\end{array}$ & - & - & - & 0,49 \\
\hline Chiarelli & $\begin{array}{l}\text { Identification of } \\
\text { geographic scope and } \\
\text { products and services }\end{array}$ & $\begin{array}{l}\text { Infrastructure and } \\
\text { brand }\end{array}$ & $\begin{array}{l}\text { Substitute } \\
\text { products, } \\
\text { internal rivalry, } \\
\text { and consumers }\end{array}$ & Yes & 0,02 \\
\hline GPC & $\begin{array}{l}\text { Identification of } \\
\text { geographic scope and } \\
\text { products and services; } \\
\text { market share estimates }\end{array}$ & - & Consumers & - & $-1,81$ \\
\hline RedeE & $\begin{array}{l}\text { Identification of } \\
\text { geographic scope and } \\
\text { products and services }\end{array}$ & - & - & - & $-0,01$ \\
\hline Sansuy & $\begin{array}{l}\text { Identification of } \\
\text { geographic scope and } \\
\text { products and services }\end{array}$ & Brand and teamwork & $\begin{array}{l}\text { Suppliers, } \\
\text { internal rivalry, } \\
\text { entry, and } \\
\text { consumers }\end{array}$ & Yes & 0,26 \\
\hline Schlosser & $\begin{array}{l}\text { Identification of } \\
\text { geographic scope and } \\
\text { products and services }\end{array}$ & Infrastructure & - & Yes & 0,00 \\
\hline Sjose & $\begin{array}{l}\text { Identification of } \\
\text { products and services }\end{array}$ & $\begin{array}{l}\text { Operational } \\
\text { characteristics, } \\
\text { production flexibility, } \\
\text { and geographic } \\
\text { location }\end{array}$ & $\begin{array}{l}\text { Suppliers and } \\
\text { consumers }\end{array}$ & - & $-1,40$ \\
\hline Tecnosolo & $\begin{array}{l}\text { Identification of } \\
\text { geographic scope and } \\
\text { products and services }\end{array}$ & $\begin{array}{l}\text { Technology, team } \\
\text { competence, } \\
\text { employee training, } \\
\text { partnerships with other } \\
\text { companies, innovation, } \\
\text { and brand }\end{array}$ & $\begin{array}{l}\text { Internal rivalry } \\
\text { and suppliers }\end{array}$ & Yes & $-4,62$ \\
\hline Teka & $\begin{array}{l}\text { Identification of } \\
\text { geographic scope and } \\
\text { products and services }\end{array}$ & Infrastructure & $\begin{array}{l}\text { Internal rivalry } \\
\text { and consumers }\end{array}$ & - & $-2,71$ \\
\hline
\end{tabular}

It is noteworthy that by calculating the EBITDA ratio, we are analyzing the performance of firms in a standardized way. However, our intention is not to perform a comparison between the companies. The intention is to examine the relationship among the strategic elements of the reorganization plan and performance. 


\section{Data analysis}

We link the strategic components of the plans to the performance of the firms by means of a qualitative comparative analysis (QCA). QCA is a methodology developed initially in social sciences, particularly in political science (Rihoux \& Ragin, 2009). One of the primary benefits of the QCA methodology is the possibility of working with small samples in a more generalizable way in comparison to the traditional methods of case study and discourse analysis.

The fundamental idea of QCA is to enable researchers to look for logical patterns of the presence and absence of specific conditions included in a theoretical model. QCA addresses multiple conjunctural causation - i.e., different configurations may lead to a similar outcome. For instance, when analyzing reorganization plans, it might be possible that (a) the definition of the relevant market along with the analysis of internal resources and (b) the description of the competitive strengths of the company may both be associated to a successful turnaround.

QCA resorts to two logical concepts: sufficiency and necessity. When analyzing which are the combinations of strategic components that influence companies to turnaround, a particular component may be unambiguously connected to the recovery of the firm - making it a sufficient condition for success. Another strategic component may not be the only condition for the recovery of the company, but its presence is a necessary condition. This means that success will be achieved only if this component, along with others, is included in the reorganization plan.

The QCA method is performed by means of a Boolean algorithm to assess whether any combination of strategic components is sufficient or necessary. The Boolean algorithm is a technique to express causal conditions in a formal, logical way. As described by Greckhamer, Misangyi, Elms and Lacey (2008),

this algorithm first establishes the number of logically possible groupings of all Boolean attributes included in the study. ... These groupings incorporate all possible causal conditions [e.g., strategic components of the reorganization plan]: all single causal factors ..., all causal combinations including two attributes ..., and so on. The algorithm consequently assesses the probabilistic sufficiency of each combination of attributes ... based on the a priori benchmark of sufficiency set by the researcher .... In the final step, the algorithm uses the containment rule to minimize the Boolean equation of all those combinations of attributes that pass the test of sufficiency (p. 717).

In its simplest form, QCA involves the building of crisp sets, i.e., sets that are dichotomous in nature. This means that all cases under investigation are classified into mutually exclusive groups. In our case, one would expect that the companies were divided into two groups: successful and unsuccessful turnarounds. However, because the bankruptcy proceedings occurred at different moments in time, the analysis of the recovery of firms is less clear. Therefore, we assess the cases with reference to a common standard - i.e., positive or negative EBITDA variation.

With regard to the strategic components, we base our analysis not just on the presence of a specific component but also on its quality. In doing so, we are working not with crisp sets but with fuzzy sets. A fuzzy set involves "varying the degree to which different cases belong to a set" 
(Rihoux \& Ragin, 2009, p. 90). A fuzzy set does not merely rank cases comparatively; it varies the degree of full inclusion or full exclusion of a particular case in a group. Accordingly, we use fuzzyset QCA (fsQCA) to account for the dispersion of conditions between fully-in and fully-out. The logic behind the fsQCA is similar to the crisp-set QCA. To perform the analysis, we used the Direct Method of Calibration over our raw database to guarantee the correct estimation of conditions into the fully-in, partially-in, partially-out, and fully-out spectrum. Table 5 shows the final calibrated table, i.e., the final quality indexes for each dimension of each company analyzed.

Table 5

Direct method of calibration scores

\begin{tabular}{lccccccc}
\hline & Diagnosis & $\begin{array}{c}\text { Relevant } \\
\text { market }\end{array}$ & $\begin{array}{c}\text { Resource } \\
\text { analysis }\end{array}$ & $\begin{array}{c}\text { Industry } \\
\text { analysis }\end{array}$ & $\begin{array}{c}\text { Competitive } \\
\text { strengths and } \\
\text { weaknesses }\end{array}$ & $\begin{array}{c}\text { Positive } \\
\text { EBTIDA } \\
\text { variation }\end{array}$ & $\begin{array}{c}\text { Negative } \\
\text { EBITDA } \\
\text { Variation }\end{array}$ \\
\hline Buettener & 0.99 & 0.00 & 0.82 & 0.08 & 0.08 & 0.00 & 1.00 \\
Celpa & 0.01 & 0.35 & 0.01 & 0.01 & 0.01 & 1.00 & 0.00 \\
Chiarelli & 0.99 & 0.03 & 0.92 & 0.99 & 0.82 & 1.00 & 0.00 \\
GPC & 0.82 & 0.82 & 0.01 & 0.18 & 0.01 & 0.00 & 1.00 \\
RedeE & 0.01 & 0.18 & 0.01 & 0.01 & 0.01 & 0.00 & 1.00 \\
Sansuy & 0.99 & 0.18 & 0.65 & 1.00 & 0.82 & 1.00 & 0.00 \\
Schlosser & 0.18 & 0.08 & 0.65 & 0.01 & 0.35 & 0.00 & 0.00 \\
Sjose & 0.82 & 0.08 & 0.65 & 0.82 & 0.01 & 0.00 & 1.00 \\
Tecnosolo & 0.82 & 0.18 & 0.97 & 0.18 & 0.92 & 0.00 & 1.00 \\
Teka & 0.65 & 0.08 & 0.65 & 0.18 & 0.01 & 0.00 & 1.00 \\
\hline
\end{tabular}

After calibrating the database, we need to set the consistency and frequency thresholds. The consistency threshold relates to the degree of membership in which a configuration is a subset of the final outcome (Ragin, 2006). In other words, consistency evaluates how much a given configuration is associated with the expected outcome. We set consistency threshold at 0.800 following the literature (Bell, Filatotchev, \& Aguilera, 2014; Fiss, 2007, 2011) and after analyzing the truth table results in Table $6^{8}$. 
Table 6

Truth tables both on positive and negative EBITDA variation

\begin{tabular}{|c|c|c|c|c|c|c|c|}
\hline \multicolumn{8}{|c|}{ Positive EBITDA variation } \\
\hline Diagnosis & $\begin{array}{c}\text { Relevant } \\
\text { market }\end{array}$ & $\begin{array}{l}\text { Resource } \\
\text { analysis }\end{array}$ & $\begin{array}{l}\text { Industry } \\
\text { analysis }\end{array}$ & $\begin{array}{l}\text { Competitive } \\
\text { strengths and } \\
\text { weaknesses }\end{array}$ & $\begin{array}{l}\text { Number of } \\
\text { cases in the } \\
\text { configuration }\end{array}$ & $\begin{array}{l}\text { Positive } \\
\text { EBTIDA } \\
\text { variation }\end{array}$ & Consistency \\
\hline 1 & 0 & 1 & 1 & 1 & 2 & 1 & 0.827 \\
\hline 1 & 0 & 1 & 1 & 0 & 1 & 0 & 0.266 \\
\hline 0 & 0 & 0 & 0 & 0 & 2 & 0 & 0.256 \\
\hline 1 & 1 & 0 & 0 & 0 & 1 & 0 & 0.018 \\
\hline 1 & 0 & 1 & 0 & 1 & 1 & 0 & 0.018 \\
\hline 0 & 0 & 1 & 0 & 0 & 1 & 0 & 0.015 \\
\hline 1 & 0 & 1 & 0 & 0 & 2 & 0 & 0.010 \\
\hline \multicolumn{8}{|c|}{ Negative EBITDA variation } \\
\hline Diagnosis & $\begin{array}{c}\text { Relevant } \\
\text { market }\end{array}$ & $\begin{array}{l}\text { Resource } \\
\text { analysis }\end{array}$ & $\begin{array}{l}\text { Industry } \\
\text { analysis }\end{array}$ & $\begin{array}{l}\text { Competitive } \\
\text { strengths and } \\
\text { weaknesses }\end{array}$ & $\begin{array}{l}\text { Number of } \\
\text { cases in the } \\
\text { configuration }\end{array}$ & $\begin{array}{c}\text { Negative } \\
\text { EBITDA } \\
\text { variation }\end{array}$ & Consistency \\
\hline 1 & 1 & 0 & 0 & 0 & 1 & 1 & 0.911 \\
\hline 1 & 0 & 1 & 0 & 0 & 2 & 1 & 0.897 \\
\hline 1 & 0 & 1 & 0 & 1 & 1 & 1 & 0.825 \\
\hline 1 & 0 & 1 & 1 & 0 & 1 & 0 & 0.727 \\
\hline 0 & 0 & 0 & 0 & 0 & 2 & 0 & 0.609 \\
\hline 0 & 0 & 1 & 0 & 0 & 1 & 0 & 0.489 \\
\hline 1 & 0 & 1 & 1 & 1 & 2 & 0 & 0.168 \\
\hline
\end{tabular}

The frequency threshold refers to the minimum number of cases we want each configuration to have in order to be included in the final solution. As our sample size is quite small, we followed literature recommendations and set our frequency threshold at one case (Rihoux \& Ragin, 2009). Moreover, we considered the intermediate QCA solutions generated by the fsQCA software on our result analysis. The intermediate solutions emerge as the most adequate because it enables us to evaluate both central and contributing conditions in our model.

Finally, we performed a necessity analysis to check which conditions were indeed necessary (Dwivedi, Joshi, \& Misangyi, 2018). Mind that fsQCA uses the probabilistic concept of quasisufficiency: a causal condition can be (a) almost always sufficient, when it passes a significance benchmark of 0.8 , (b) usually sufficient, when it passes a significance benchmark of 0.65 , or (c) sufficient more than not, when it passes a significance benchmark of 0.5 (Ragin, 2000). Because we are examining 10 cases, the statistical significance of quasi-sufficiency is assessed using binomial probabilities. 


\section{Findings}

Table 7 presents the key elements listed by companies in their reorganization plans as causing the problems they face. In general, firms associate the origin of their problems with the rising cost of capital, either due to an increase in interest rates by the Brazilian Central Bank or due to the deterioration of their own financial conditions. Another element cited repeatedly by companies is the rise in production costs through, for example, the abrupt increase in prices of raw materials. Increased competition and the influence of the instability caused by global financial crisis are also mentioned. Some companies attribute their crisis to the fragility of their management processes, which fail to meet the external contingencies. 
Table 7

\section{Reorganization plans: diagnosis of the factors causing the crisis-main arguments}

\begin{tabular}{|c|c|c|c|c|c|c|c|c|}
\hline Company & $\begin{array}{l}\text { Increased competition } \\
\text { from foreign and national } \\
\text { companies }\end{array}$ & $\begin{array}{l}\text { Increase in } \\
\text { costs }\end{array}$ & $\begin{array}{l}\text { International } \\
\text { financial crisis }\end{array}$ & $\begin{array}{l}\text { Crisis in } \\
\text { business } \\
\text { segment }\end{array}$ & $\begin{array}{l}\text { Domestic } \\
\text { currency } \\
\text { appreciation }\end{array}$ & $\begin{array}{l}\text { Increase in the cost of } \\
\text { capital (e.g., higher } \\
\text { interest rates) }\end{array}$ & $\begin{array}{l}\text { Management } \\
\text { decisions }\end{array}$ & $\begin{array}{l}\text { Change in public } \\
\text { policy for the } \\
\text { industry }\end{array}$ \\
\hline 1 & $x$ & $x$ & & $x$ & & $x$ & $x$ & \\
\hline \multicolumn{9}{|l|}{2} \\
\hline 3 & & $x$ & & & $x$ & $x$ & $x$ & \\
\hline 4 & & $x$ & $x$ & & & $x$ & & \\
\hline \multicolumn{9}{|l|}{5} \\
\hline 6 & $x$ & $x$ & & & $x$ & $x$ & $x$ & \\
\hline 7 & & & & $x$ & & & $x$ & \\
\hline 8 & & $x$ & $x$ & & & $x$ & & $x$ \\
\hline 9 & $x$ & & $x$ & & & $x$ & $x$ & \\
\hline 10 & $x$ & $x$ & & $x$ & & $x$ & & \\
\hline
\end{tabular}

Note. Source: elaborated by the authors, based on companies' reorganization plans. 
We report in Table 8 the QCA results. The estimations are based on the quality rankings of the plans' components. The table shows that not just one but two configurations are associated to a negative EBITDA variation. In the case of a positive EBITDA variation, there is one configuration. For each configuration (solution), a different pattern of present and absent strategic components exists.

Table 8

fsQCA results on both positive and negative EBITDA variation

\begin{tabular}{lccc}
\hline Strategic components & $\begin{array}{c}\text { Positive EBITDA } \\
\text { variation }\end{array}$ & $\begin{array}{c}\text { Negative EBITDA } \\
\text { variation }\end{array}$ & $\begin{array}{c}\text { Negative EBITDA } \\
\text { variation }\end{array}$ \\
\hline & 1 & $2 \mathrm{a}$ & $2 \mathrm{~b}$ \\
Diagnosis & $\bullet$ & $\bullet$ & $\bullet$ \\
Relevant market & $\otimes$ & $\otimes$ & $\otimes$ \\
Resource analysis & $\bullet$ & $\otimes$ & $\otimes$ \\
Industry analysis & $\bullet$ & Buettener, Technosolo, & GPC \\
Competitive strengths and weaknesses & $\bullet$ & and Teka & 0.911 \\
Representative cases & Chiarelli and Sansuy & 0.926 & 0.170 \\
Consistency & 0.827 & 0.415 & 0.135 \\
Raw coverage & 0.493 & 0.380 & \\
Unique coverage & 0.493 & & 0.943 \\
Overall solution consistency & 0.827 & 0.550 & \\
Overall solution coverage & 0.493 & & $\otimes$
\end{tabular}

Note. Central conditions are represented by $\bullet$ (presence) and $\otimes$ (absence); contributing conditions by $\bullet$ (presence) and $\otimes$ (absence); blank spaces indicate a "don't care" condition-that is, the condition is not relevant to that particular configuration. Minimum thresholds used in the analysis have consistency of 0.8 and frequency of one case per configuration.

We also report in the table some measures related to the estimations. The overall solution coverage refers to the explanatory power of the solutions, i.e., how much of the outcome is covered by all configurations (Rihoux \& Ragin, 2009). In our model, the two identified solutions associated to a negative EBITDA variation account for $55.5 \%$ of the membership in the outcome. The solution associated to the positive EBITDA variation accounts for $49.3 \%$ of the membership.

In addition, two measures are available to determine the fit of each configuration (Ragin, 2006; Tóth, Thiesbrummel, Henneberg, \& Naudé, 2015). As mentioned, consistency measures the extent to which the configuration relates to the outcome (Ragin, 2006, 2008). All of the six identified solutions exceed 0.80 and thus can be considered sufficient for achieving the outcome (Ragin, 2006, 2008). The coverage assesses the percentage of cases that are associated to a particular configuration, expressing the empirical importance of an identified solution (Fiss, 2007). The raw coverage measures the proportion of memberships in the outcome explained by each strategic component of the solution. The unique coverage quantifies the proportion explained only by one solution, excluding memberships that are covered by other solutions (Ragin, 2006). All solutions have unique coverage greater than zero, which means that at least one case is associated with that configuration (Tóth et al., 2015). 
Accordingly, a positive EBITDA (solution 1) is associated with the presence of almost all strategic components combined. A successful result will be reached if the firm has a clear diagnosis of the crises, performed an adequate resource and industry analysis, and clearly identified its competitive strengths and weaknesses. Surprisingly, the clear identification of the firm's relevant market was negligible and appeared to be absent for a positive outcome. Meanwhile, for a negative EBITDA (solutions $2 \mathrm{a}$ and $2 \mathrm{~b}$ ), the main message is even more straightforward. The company may have made a perfect diagnosis and may even have included a resource assessment in the plan; however, if the firm has not performed a satisfactory industry analysis, the recovery plan is bound to fail. In light of this evidence, we performed a necessity analysis (see Table 9) to check whether the absence of the industry analysis is a necessary condition for a reorganization plan to fail. We found evidence that the absence of the industry analysis is "more often than not" associated with a negative EBITDA $(p<0.1)$.

Table 9

Necessity analysis to negative EBITDA variation

\begin{tabular}{lll}
\hline Negative EBITDA variation & Consistency & p-value for consistency benchmark of 0.5 ("more often than not") \\
\hline$\sim$ Industry analysis & 0.76 & $0.063^{*}$ \\
\hline
\end{tabular}

Note. ${ }^{* *} p<0.01 ;{ }^{* *} p<0.05$, and ${ }^{*} p<0.10$. Since we have less than 10 cases, instead of following the formula using the binomial-normal approximation, we used the binomial distribution (Ragin, 2000) to conduct our hypothesis tests assuming successes and failures were strictly binary considering our estimated consistency and the number of causal attributes/combinations under analysis. In addition, no variable appears to be necessary to a positive EBITDA variation even in a 0.5 benchmark.

\section{Discussion}

In line with our empirical analysis, there are roads and turnoffs in the stage of reorganization plan formulation where managers can get lost. This may confront the usual thinking. For instance, one could argue that the diagnosis of the factors causing the crisis is essential for the construction of the remaining stages of strategic analysis. As such, a superior diagnosis would provide enough evidence that managers have a non-biased view of the company's problems and have the ability to lead the recovery process, even in the absence of other strategic ingredients. The same argument, but in reverse, applies to the case of good industry analysis. According to this line of reasoning, when talking properly about the competitive forces that affect the firm, managers indicate that they might be able to perform, even if implicitly, the other steps of strategic analysis. Nevertheless, this does not seem to be enough.

The evidence suggests that there is the need for the plan to be detailed in the strategic dimensions. This increases in likelihood with greater participation of key stakeholders (e.g., significant creditors and the court) in developing and implementing the plan (Baldiga, 1996) so that the stakeholders can assess the overall managerial competencies of the individuals involved in the turnaround process. The underlying idea is that the successful turnaround process requires managers to go beyond retrenchment or focus only on financial issues to take account of a firm's external stakeholders and internal processes (Arogyaswamy, Barker, \& Yasai-Ardekani, 1995). 
Our analysis also suggests that reorganization plans based on all strategic ingredients except the relevant market are associated with the improvement of the financial situation of the company. As long as this result is not intuitive, it deserves to be explained by a strong prediction. We identify two possible explanations. The first and most naive explanation is that relevant market analysis is unimportant. This type of argument is naive to the extent that the court and the creditors may not necessarily have knowledge on the particular aspects of the industry, and so managers should be able to clearly articulate the competitive space of the firm. The second explanation is that strategic analysis (mainly, industry analysis) makes the detailed definition of the relevant market disposable, since it already takes account of the majority of the influences on competition (Porter, 2001).

\section{Managerial implications}

Our study has several implications for managers. The most important is that managers involved in corporate reorganization processes should pay more attention to the formatting of reorganization plans. A plan should be seen as a storybook, with an introduction, a development and a closing. A plan that reports only the retrenchment actions or the diagnosis of the crisis is like a ripped book with a missing part. Managers should go beyond the financial and immediate aspects of the turnaround and deliberately introduce strategic ingredients in reorganization plans. It is not enough to present a good diagnosis of the causative factors of the crisis and/or a good description of the strengths and weaknesses of the firm. Managers should also devote time to analyzing and communicating about the resources of the firm and the industry forces that shape the strategic decisions.

\section{Limitations}

Our study has several limitations. The most apparent is the fact that we base our analysis on a reduced set of reorganization bankruptcy cases from an emerging country. Future studies may broaden the research base. It would also be particularly interesting to include a country with a longstanding reorganization bankruptcy law and with a distinct legal tradition - for instance, the UK or the US. There are also limitations on the conclusions driven by the QCA methodology. The method will always address the presence and absence of any conditions included in the model. Thus, each additional factor/condition/variable included in the sample will improve exponentially the range of possible outcome combinations. A balance among the number of variables and cases is necessary to prevent a significant increase in complexity focusing on particularities that may disturb the final analysis.

\section{Conclusions}

This exploratory paper is about strategic planning for the recovery of distressed firms and not about the turnaround process per se. The object of the analysis is reorganization plans. Although a good reorganization plan is not a guarantee of success, the plan is the heart of the process of reorganization bankruptcy. It serves as the roadmap for the firm's turnaround, and it is the core

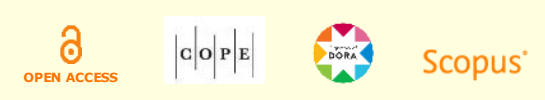


element whose feasibility the court assesses to decide on the request for bankruptcy reorganization. That is to say, the reorganization plan plays a role in the process of business recovery. Although the literature on turnaround is extensive, we consider that an analysis of the reorganization plans can bring new insights into the turnaround strategies used by companies (Schweizer \& Nienhaus, 2017) and the decision process and practice in times of organizational decline (Serra et al., 2017). Our study is a step in this direction, showing how the strategic components of reorganization plans relate to firm performance.

\section{Notes}

${ }^{1}$ Trahms, Ndofor and Sirmon (2013) present an updated version of Pearce and Robbins' (1993) model. The argument we develop here may be applied straightforwardly to this updated model without any loss in generality.

${ }^{2}$ See Schmitt and Raisch (2013) for a discussion on the duality of retrenchment and recovery.

${ }^{3}$ The creditors of a bankrupt firm are generally divided into different classes, according to priority in the payment of past due amounts.

${ }^{4}$ See Musacchio (2009) for a historical account of the development of bankruptcy law in Brazil.

${ }^{5}$ Access to plan involves access to restricted directories of the courts' websites.

${ }^{6}$ Lazzarini, Musacchio, Bandeira-de-Mello and Marcon (2015) and Nickerson and Silverman (2003) use a ratio between EBITDA and assets as a dependent variable. Our case is similar given that we are working with EBITDA ratio, and assuming that the assets would cancel out since they are less liquid than EBITDA.

${ }^{7}$ The choice of a three-year period to build the performance indicator could be criticized because it can influence the QCA outcome. To address this issue, we performed a sensitivity analysis by calculating the EBITDA ratio and performing the QCA analysis taking as a reference different periods, ranging from one to four years. The results obtained do not vary greatly. We chose a three-year period because (a) it generates a more balanced distribution of positive and negative EBITDA indicators, and (b) it generates an overall solution consistency of 100 percent in the case of positive variation of EBITDA.

${ }^{8}$ Notice that in both positive and negative truth tables presented in Table 8 , there is a jump in the consistency scores at 0.800 , which reinforces the adequacy of 0.800 as the correct consistency threshold.

\section{References}

Anapolsky, J. M., \& Woods, J. F. (2013). Pitfalls in Brazilian bankruptcy law for international bond investors. Journal of Business $\quad \mathcal{F}$ Technology Law, 8(2), 397-450. Retrieved from https://digitalcommons.law.umaryland.edu/jbtl/vol8/iss2/4

Araujo, A., Ferreira, R. V. X., \& Funchal, B. (2012). The Brazilian bankruptcy law experience. Joumal of Corporate Finance, 18(4), 994-1004. https://doi.org/10.1016/j.jcorpfin.2012.03.001

Araujo, A., \& Funchal, B. (2009). A nova lei de falências brasileira: Primeiros impactos. Brazilian Journal of Political Economy, 29(3), 191-212. http://dx.doi.org/10.1590/S0101-31572009000300011

Arogyaswamy, K., Barker, V. L., \& Yasai-Ardekani, M. (1995). Firm turnarounds: An integrative two-stage model. Journal of Management Studies, 32(4), 493-525. https://doi.org/10.1111/j.1467-6486.1995.tb00786.x

Baker, D. D., \& Cullen, J. B. (1993). Administrative reorganization and configurational context: The contingent effects of age, size, and change in size. Academy of Management Journal, 36(6), 1251-1277. https://doi.org/10.2307/256811

Baker, V. L., \& Duhaime, I. M. (1997). Strategic change in the turnaround process: Theory and empirical evidence. Strategic Management Journal, 18(1), 13-38. https://doi.org/10.2307/3088193 
Baldiga, N. R. (1996). Is this plan feasible? An empirical legal analysis of plan feasibility. Commercial Law Journal, 101(2), 115-133.

Barney, J. B. (1991). Firm resources and sustained competitive advantage. Journal of Management, 17(1), 99-120. https://doi.org/10.1177/014920639101700108

Barney, J. B., \& Clark, D. N. (2007). Resource-based theory creating and sustaining competitive advantages (1st ed.). Oxford, New York, NY: Oxford University Press.

Bell, R. G., Filatotchev, I., \& Aguilera, R. V. (2014). Corporate governance and investors' perceptions of foreign IPO value: An institutional perspective. Academy of Management Journal, 57(1), 301-320. https://doi.org/10.5465/amj.2011.0146

Bellini, C. G. P., Palvia, P., Moreno, V., Jacks, T., \& Graeml, A. (2019). Should I stay or should I go? A study of IT professionals during a national crisis. Information Technology $\mathscr{E}$ People, 32(6), 1472-1495. https://doi.org/10.1108/ITP-07-2017-0235

Besanko, D., Dranove, D., Shanley, M., \& Schaefer, S. (2009). Economics of strategy. New York, NY: Wiley. https://doi.org/10.1093/ntr/nts298

Boyne, G. A., \& Meier, K. J. (2009). Environmental change, human resources and organizational turnaround. Journal of Management Studies, 46(5), 835-863. https://doi.org/10.1111/j.1467-6486.2008.00813.x

Cohen, J. (1960). A coefficient of agreement of nominal scales. Educational and Psychological Measurement, 20(1), 37 46. https://doi.org/10.1177/001316446002000104

Confirmation of Plan, 11 U.S.C. $\$ 1129$. (2019).

Cronbach, L. J. (1951). Coefficient alpha and the internal structure of tests. Psychometrika, 16(3), 297-334. https://doi.org/10.1007/BF02310555

Daily, C. M. (1994). Bankruptcy in strategic studies: Past and promise. Journal of Management, 20(2), 263-295. https://doi.org/10.1016/0149-2063(94)90017-5

Damodaran, A. (2001). The dark side of valuation: Valuing old tech, new tech, and new economy companies. Upper Saddle River, NJ: Prentice-Hall.

D'Aveni, R. A. (1989). The aftermath of organizational decline: A longitudinal study of the strategic and managerial characteristics of declining firms. Academy of Management Journal, 32(3), 577-605. https://doi.org/10.2307/256435

Decreto-lei $n^{o}$ 7.661, de 21 de junho de 1945. (1945). Dispõe sobre lei de falências. Retrieved from http://www.planalto.gov.br/ccivil_03/Decreto-Lei/Del7661.htm

Dwivedi, P., Joshi, A., \& Misangyi, V. F. (2018). Gender-inclusive gatekeeping: How (mostly male) predecessors influence the success of female CEOs. Academy of Management Journal, 61(2), 379-404. https://doi.org/10.5465/amj.2015.1238

Fiss, P. C. (2007). A set-theoretic approach to organizational configurations. Academy of Management Review, 32(4), 1180-1198. https://doi.org/10.5465/amr.2007.26586092

Fiss, P. C. (2011). Building better causal theories: A fuzzy set approach to typologies in organization research. Academy of Management Journal, 54(2), 393-420. https://doi.org/10.5465/AMJ.2011.60263120

Flynn, D. M., \& Farid, M. (1991). The intentional use of chapter XI: Lingering versus immediate filing. Strategic Management Joumal, 12(1), 63-74. https://doi.org/10.1002/smj.4250120106

Funchal, B. (2008). The effects of the 2005 bankruptcy reform in Brazil. Economics Letters, 101(1), 84-86. https://doi.org/10.1016/j.econlet.2008.06.008

Greckhamer, T., Misangyi, V. F., Elms, H., \& Lacey, R. (2008). Using qualitative comparative analysis in strategic management research: An examination of combinations of industry, corporate, and business-unit effects. Organizational Research Methods, 11(4), 695-726. https://doi.org/10.1177\%2F1094428107302907

Hofer, C. W. (1980). Turnaround strategies. Joumal of Business Strategy, 1(1), $19-31$. https://doi.org/10.1108/eb038886 
Hooley, G., \& Greenley, G. (2005). The resource underpinnings of competitive positions. Journal of Strategic Marketing, 13(2), 93-116. https://doi.org/10.1080/09652540500082968

Lazzarini, S. G., Musacchio, A., Bandeira-de-Mello, R., \& Marcon, R. (2015). What do state-owned development banks do? Evidence from BNDES, 2002-09. World Development, 66, 237-253. https://doi.org/10.1016/j.worlddev.2014.08.016

Lei no. 11.101, de 9 de fevereiro de 2005. (2005). Regula a recuperação judicial, a extrajudicial e a falência do empresário e da sociedade empresária. Retrieved from http://www.planalto.gov.br/ccivil_03/_ato20042006/2005/lei/111101.htm

Lim, D. S. K., Celly, N., Morse, E. A., \& Rowe, W. G. (2013). Rethinking the effectiveness of asset and cost retrenchment: The contingency effects of a firm's rent creation mechanism. Strategic Management Journal, 34(1), 42-61. https://doi.org/10.1002/smj.1996

Madhok, A. (2002). Reassessing the fundamentals and beyond: Ronald Coase, the transaction cost and resourcebased theories of the firm and the institutional structure of production. Strategic Management Journal, 23(6), 535550. https://doi.org/10.1002/smj.247

Mahoney, J. T., \& Pandian, J. R. (1992). The resource-based view within the conversation of strategic management. Strategic Management Journal, 13(5), 363-380. https://doi.org/10.1002/smj.4250130505

McGahan, A. M., \& Porter, M. E. (1997). How much does industry matter, really? Strategic Management Journal, 18(S1), 15-30. https://doi.org/10.1002/(sici)1097-0266(199707)18:1+\%3C15::aid-smj916\%3E3.3.co;2-t

Moulton, W. N., \& Thomas, H. (1993). Bankruptcy as a deliberate strategy: Theoretical considerations and empirical evidence. Strategic Management Journal, 14(2), 125-135. https://doi.org/10.2307/2486540

Muñoz-Izquierdo, N., Segovia-Vargas, M. J., Camacho-Miñano, M.-M., \& Pascual-Ezama, D. (2019). Explaining the causes of business failure using audit report disclosures. Journal of Business Research, 98, 403-414. https://doi.org/10.1016/j.jbusres.2018.07.024

Musacchio, A. (2009). Experiments in financial democracy: Corporate governance and financial development in Brazil, 1882. 1950 (1st ed.). New York, NY: Cambridge University Press.

Nickerson, J. A., Hamilton, B. H., \& Wada, T. (2001). Market position, resource profile, and governance: Linking Porter and Williamson in the context of international courier and small package services in Japan. Strategic Management Journal, 22(3), 251-273. https://doi.org/10.1002/smj.159

Nickerson, J. A., \& Silverman, B. S. (2003). Why firms want to organize efficiently and what keeps them from doing so: Inappropriate governance, performance, and adaptation in a deregulated industry. Administrative Science Quarterly, 48(3), 433-465. https://doi.org/10.2307/3556680

O’Neill, H. M. (1986). Turnaround and recovery: What strategy do you need? Long Range Planning, 19(1), 80-88. https://doi.org/10.1016/0024-6301(86)90131-7

Pearce, J. A., \& DiLullo, S. A. (1998). When a strategic plan includes bankruptcy. Business Horizons, 41(5), 67-73. https://doi.org/10.1016/s0007-6813(98)90080-5

Pearce, J. A., \& Robbins, D. K. (1993). Toward improved theory and research on business turnaround. Journal of Management, 19(3), 613-636. https://doi.org/10.1177/014920639301900306

Peteraf, M. A. (1993). The cornerstone of competitive advantage: A resource-based view. Strategic Management Journal, 14(3), 179-191. https://doi.org/10.1002/smj.4250140303

Pleatsikas, C., \& Teece, D. (2001). The analysis of market definition and market power in the context of rapid innovation. International Joumal of Industrial Organization, 19(5), 665-693. https://doi.org/10.1016/S01677187(00)00088-6

Porter, M. E. (1985). Competitive advantage: Creating and sustaining superior performance. New York, NY: The Free Press.

Porter, M. E. (2001). Competition and antitrust: Towards a productivity-based approach to evaluating mergers and joint ventures. University of West Los Angeles Law Review, 33, 17-34. 
Ragin, C. C. (2000). Fuzzy-set social science. Chicago, IL: University of Chicago Press.

Ragin, C. C. (2006). Set relations in social research: Evaluating their consistency and coverage. Political Analysis, 14(3), 291-310. https://doi.org/10.1093/pan/mpj019

Ragin, C. C. (2008). Redesigning social inquiry: Fuzzy sets and beyond. Annals of Physics, 54(2), 225-235. https://doi.org/10.7208/chicago/9780226702797.001.0001

Rihoux, B., \& Ragin, C. C. (Eds.) (2009). Configurational comparative methods: Qualitative comparative analysis (QCA) and related techniques. Thousand Oaks, CA: Sage Publications.

Schmitt, A., \& Raisch, S. (2013). Corporate turnarounds: The duality of retrenchment and recovery. Journal of Management Studies, 50(7), 1216-1244. https://doi.org/10.1111/joms.12045

Schweizer, L., \& Nienhaus, A. (2017). Corporate distress and turnaround: Integrating the literature and directing future research. Business Research, 10(1), 3-47. https://doi.org/10.1007/s40685-016-0041-8

Serasa Experian. (2019). Indicadores econômicos. https://www.serasaexperian.com.br/amplie-seusconhecimentos/indicadores-economicos

Serra, F. A. R., Pinto, R., Guerrazzi, L., \& Ferreira, M. P. (2017). Organizational decline research review: Challenges and issues for a future research agenda. Brazilian Administration Review, 14(2), e160110. https://doi.org/10.1590/1807-7692bar2017160110

Sheehan, N. T., \& Foss, N. J. (2017). Using Porterian activity analysis to understand organizational capabilities. Journal of General Management, 42(3), 41-51. https://doi.org/10.1177/0306307017690518

Sheppard, J. P. (1994). Strategy and bankruptcy: An exploration in to organizational death. Journal of Management, 20(4), 795-883. https://doi.org/10.1177/014920639402000406

Thornhill, S., \& Amit, R. (2003). Learning about failure: Bankruptcy, firm age, and the resource-based view. Organization Science, 14(5), 497-509. https://doi.org/10.1287/orsc.14.5.497.16761

Tóth, Z., Thiesbrummel, C., Henneberg, S. C., \& Naudé, P. (2015). Understanding configurations of relational attractiveness of the customer firm using fuzzy set QCA. Journal of Business Research, 68(3), 723-734. https://doi.org/10.1016/j.jbusres.2014.07.010

Trahms, C. A., Ndofor, H. A., \& Sirmon, D. G. (2013). Organizational decline and turnaround: A review and agenda for future research. Journal of Management, 39(5), 1277-1307. https://doi.org/10.1177/0149206312471390

Vaz, J. C. M. (2018). Recuperação judicial de empresas: Atuação do juiz. São Paulo, Brazil: Almedina.

\section{Author contributions}

$1^{\text {st }}$ author: conceptualization (equal), data curation (equal), formal analysis (equal), methodology (equal), supervision (equal), writing-original draft (equal), writing-review and editing (equal).

$2^{\text {nd }}$ author: conceptualization (equal), writing-original draft (equal), writing-review and editing (equal).

$3^{\text {rd }}$ author: investigation (equal), methodology (equal), software (equal), validation (equal), writing-original draft (equal), writing-review and editing (equal), 


\section{Authors}

\section{Guilherme Fowler A. Monteiro}

Insper Instituto de Ensino e Pesquisa

Rua Quata, 300, 04546-042, São Paulo, SP, Brazil

guilhermefam@insper.edu.br

(iD) https://orcid.org/0000-0003-2689-1094

\section{Silvia Morales de Q. Caleman}

Universidade Federal de Mato Grosso do Sul, Escola de Administração e Negócios

Av. Senador Filinto Muller, 1015, Cidade Universitária, Unidade 10, 79046-460, Campo Grande, MS, Brazil silvia.caleman@ufms.br

(iD) https://orcid.org/0000-0001-7560-5141

\section{Leandro S. Pongeluppe}

University of Toronto, Rotman School of Management

105 St. George Street, M5S 3E6, Toronto, Ontario, Canada

L.Pongeluppe16@rotman.utoronto.ca

(iD) https://orcid.org/0000-0001-6195-4455

Peer review is responsible for acknowledging an article's potential contribution to the frontiers of scholarly knowledge on business or public administration. The authors are the ultimate responsible for the consistency of the theoretical references, the accurate report of empirical data, the personal perspectives, and the use of copyrighted material 


\section{APPENDIX}

\section{Rating Form}

\section{Company name}

$\# 1$; \#2; \#3; \#4; \#5; \#6; \#7; \#8; \#9; or \#10

\section{Dimension: diagnosis}

0. Not specified;

1. Poor description of external factors (e.g., volatility of market prices) AND of internal factors (e.g., increase in the cost structure) that negatively affect the company;

2. Clear description of external factors OR internal factors that negatively impacted the company; 3. Clear description on the connection between external factors and internal factors as well as their interdependencies in evaluating the company's performance. Arguments supported by data from reliable sources.

\section{Dimension: relevant market}

0. Not specified;

1. Poor description of company's products (product dimension) AND of the geographic area in which the company sells its products or services (geographic dimension);

2. Clear description of product dimension OR geographic dimension;

3. Clear description of product dimension AND geographic dimension;

4. Clear description of the product and geographic dimensions in conjunction with the competitive pressure (e.g., identification of competitors);

5. Development of a complete market analysis, including estimated market share of the company and industry concentration degree (e.g., HHI index), using data from reliable sources.

\section{Dimension: resource analysis}

0. Not specified;

1. Clear description of the company's main resources/capabilities, which can support its turnaround;

2. Characterization of the resources/capabilities as a source of value for the company (VRIO model (Barney, 1991; Barney \& Clark, 2007)) and of sustained competitive advantage;

3. Development of a dynamic analysis of the resources/capabilities and its impact on company's turnaround (Is the value of resources/capabilities sustainable over time?).

\section{Dimension: industry analysis}

0. Not specified;

1. Clear identification of one competitive force (as defined by Porter (1985)) that determines the competitive intensity of the industry; 
2. Clear identification of two competitive forces;

3. Clear identification of three competitive forces;

4. Clear identification of four or five competitive forces.

\section{Dimension: competitive strengths and weaknesses}

0. Not specified;

1. Poor description of company's strategies for competitive advantage;

2. Clear description of strategies for competitive advantage, accompanied by a full description of actions that will allow the company to achieve its goal;

3. Clear description of strategies for competitive advantage, accompanied by a full description of actions that will allow the company to achieve its goal. Additionally, clear identification of goals, deadlines, and key barriers to conducting such actions.

Id Rater \#1; \#2 or \#3 